\title{
LEDER
}

\section{At fortælle til andre er at fortælle sig selv - om fællesskabet som udviklingsredskab}

Rie Troelsen, ph.d., lektor, Institut for Kulturvidenskaber, Syddansk Universitet.

"Gode undervisnings- og vejledningspraksisser - hvordan?" var temaet for dette års DUN-konference. I kvantitative termer var det 18. gang DUN afholdt sin universitetspædagogiske konference, som denne gang varede to dage. Programmet bestod af paneldebat, plenarforedrag, 10 workshops og 22 præsentationer, og i alt 135 personer deltog. De fleste danske universiteter og enkelte university colleges var repræsenterede, ligesom også enkelte svenske og norske kolleger deltog. I kvalitative termer var der adskillige gennemarbejdede og reflekterede bud på gode undervisnings- og vejledningspraksisser, utallige uformelle og netværksskabende kaffesamtaler og forhåbentlig rigtig mange inspirerende og motiverende oplevelser. Efterfølgende var det muligt at indsende sit bidrag i skriftlig form til en reviewet konferencepublikation, hvilket har resulteret i bogen 17 ting du kan gøre $i$ din undervisning (Troelsen \& Rienecker, 2013), som indeholder konkrete beskrivelser af gode undervisnings- og vejledningspraksisser.

Når så mange vælger at tage sig tid til at deltage i og bidrage til en universitetspædagogisk konference, er det et tegn på, at det giver mening for den enkelte at bruge tid på det, at der er flere og flere, for hvem det giver mening, og at der er support fra baglandet til at deltage. Og alle tre aspekter er vigtige for kommende konferencers (og andre universitetspædagogiske aktiviteters) succes; det skal føles meningsfuldt og værdiskabende for den enkelte og dennes undervisningsudvikling, der skal være en kritisk masse af kolleger for dels at kvalificere diskussionerne og dels for at skabe fornemmelsen af et decideret praksisfællesskab, og det skal være anerkendt af ledelserne vha. den fornødne økonomi og de tidsmæssige ressourcer til at deltage i konferencer af denne slags (og ikke kun forskningsfaglige). Så tøv ikke et sekund med at tilmelde jer DUN-konference 2013 næste år i maj!

Temaet for konferencen var som nævnt gode undervisnings- og vejledningspraksisser, og det fører naturligvis spørgsmålet med sig om, hvad god undervisning og vejledning i grunden er. Det er der (heldigvis?) ikke nogen fast skabelon eller best practi$c e$ for - det ville være kedeligt for både undervisere og studerende. Men der er mange gode bud på, hvad god undervisning og vejledning kan være afhængig af under- 
viser, studerende, uddannelsesmål, fagtradition, undervisningslokale osv. - der er et væld af good practices. Og det er i udvekslingen af disse good practices undervisere imellem, at den egentlig udvikling af egen undervisning tager sit afsæt. Udvikling af undervisningen har nemlig svære odds, hvis undervisningen opfattes som en privat sag. "En lærerforståelse med lukkede døre og uudnyttede muligheder for kollegasamarbejde og støtte har fremtiden bag sig", som det fremhæves i indledningen til en bog om kollegavejledning (Lauvås et al., 1996, s. 9). I udviklingen af undervisning ligger udfordringen ikke i den enkeltes kompetencer, for undervisere på universiteterne er generelt kyndige, erfarne og kreative, men nærmere $\mathrm{i}$ at gøre denne individuelle viden til en fælles viden og skabe fællesskab omkring undervisningen og underviserrollen.

Det er netop, hvad DUN-konferencen og dette konferencetemanummer af DUT forsøger at gøre - at skabe et fællesskab omkring undervisning og det at undervise. Konferencen har haft som formål at skabe rum for erfaringsudveksling, og ved at eksplicitere begrundelserne for deres undervisningspraksis for sig selv og andre har oplægsholdere og workshop-ledere på konferencen ikke alene haft mulighed for at give inspiration til andre, men også at blive mere bevidste om deres egen undervisning. Konferencen kan derfor - også - ses som et refleksionsrum for deltagerne og som et led i deres selvudvikling som undervisere.

Erfaringsudvekslingen kommer dog ikke alene konferencedeltagerne til gode, men også læsere af denne publikation. Som læser bliver man ikke kun inspireret af de enkelte bidrag til $\mathrm{fx}$ at lade sine studerende selv indsamle cases, eksperimentere med nye eksamensformer eller til at arbejde aktivt med stoffet gennem individuel og gruppebaseret forberedelse og efterbehandling. Som samlet vifte giver bidragene en (god) fornemmelse af, at meget kan lade sig gøre inden for universitær undervisning, hvis man som underviser ikke alene har en pædagogisk viden og kunnen (som de fleste kan erhverve sig gennem de mange universitetspædagogiske kurser, som efterhånden findes som tilbud på universiteterne i dag), men også en pædagogisk vilje til at udvikle og forbedre sin undervisning. Undervisning kan godt være anderledes end den, man selv modtog som studerende!

En konference som denne er derfor ikke kun deltagernes mulighed for at fortælle andre om egne - vellykkede - undervisningsforløb eller tilhørernes mulighed for at lade sig inspirere. Det er i høj grad også en fælles videnstilegnelse og -udvikling, som på både kort og langt sigt kan gøre universitetsundervisningen bedre. Det er en mulighed for at bruge fællesskabet som et individuelt udviklingsredskab.

\section{Litteratur}

Lauvås, P., Lycke, K. H., \& Handal, G. (1996). Kollegavejledning i skolen. Århus: Klim. Troelsen, R., \& Rienecker, L. (2013). 17 ting du kan gøre med din undervisning - inspiration fra Dansk Universitetspædagogisk Netværks konference 2012. (In press). 